\title{
Sentencing for Minors in Sexual Abuse Cases
}

\author{
Devy Wahyuningtyas Subroto' ${ }^{1}$, Muh Endriyo Susila ${ }^{2}$ \\ 1,2 Fakultas Hukum, Universitas Muhammadiyah Yogyakarta \\ Email : ${ }^{1}$ devy.w.law16@mail.umy.ac.id \\ endriosusilo@umy.ac.id
}

\author{
Info Artikel \\ Riwayat: \\ Diajukan \\ Direvisi : 29 Agustus 2020 \\ Diterima : 23 Oktober 2020 \\ Kata Kunci : \\ minors; sentencing; sexual \\ abuse \\ DOI: \\ 10.18196/ijclc.v1i3.11261
}

\begin{abstract}
Abstrak
Sexual abuse is committed not only by adults but also by minors. The legal process upon children who have committed sexual abuse refers to the Law Number 11 of 2012 on the Juvenile Court System. The purpose of this study is to find out the factors to be considered by the panel of judges in imposing penalty upon the perpetrators. The study employs both normative and empirical approaches. It is found with regard to the liability issue, the panel of judges relies on both juridical and nonjuridical consideration. In sexual abuse case that was tried in Kebumen District Court, beside imposing imprisonment, the panel of judges also ordered the perpetrators to undergo work training as a substitute of fine.
\end{abstract}

\section{Introduction}

Violent crimes against women and children in Kebumen regency are dominated by sexual abuse cases. The forms of abuse varied including unlawful sexual intercourse against minor or obscene actions against minors. Unfortunately, some of the perpetrators were also minors. It is worrying because such cases happen every year.

Children are weak, helpless, and still dependent on adults and therefore they are vulnerable to any kind of violence. Children should be protected not only from victimization, but also from participation in crimes especially sexual abuse. Sexual abuse cases involving minors as perpetrators has become an actual phenomenon in Kebumen regency. The involvement of children in sexual crimes as occurred in Kebumen was stimulated by various factors including the development of science and technology. The advancement technology, especially information technology, brings about negative impacts to children. Children have been exposed to negative contents such as indecency that stimulate them to imitate.

The prosecution of children refers the Law Number 11 of 2012 on the Juvenile Court System. The Act suggests different approach to juvenile perpetrators as compared to adult perpetrators. The physical as well as mental condition of children should be taken into account. The criminal proceedings are inherently harmful for children. In order to protect children from the negative impact of the criminal justice system, an alternative approach called diversion has been introduced. ${ }^{1}$ Based on the background of research above, the researcher is interested in conducting a research entitled "Sentencing for minors who committed sexual abuse in Kebumen Regency".

\section{Research Problem}

A. What factors do stimulate minors to do sexual abuse?

B. What are the consideration of the judges in imposing punishment against the minor perpetrators?

\footnotetext{
${ }^{1}$ Claudia Carolina Indra Putri. (2019). Juridical Review of Restorative Justice in the Juvenile Justice System through Diversion. Indonesian Journal of Criminal Law Studies 4(1). p. 3.
} 


\section{Research Method}

The type of conducted research is combination between normative and empirical legal research. As such, the research employed both primary and secondary data. The primary data were collected through interviews upon relevant parties. While the secondary data in the form of either primary and secondary legal materials were collected through library-based study. As the research investigated sentencing system against minors, the study on the Law Number 11 of 2012 on the Juvenile Court System was dominant throughout the discussion.

In normative legal research using the perspective method, which is the method of analysis that gives an assessment (justification) of the object under study whether it is in accordance with the law. ${ }^{2}$ While the method of analysis in empirical legal research uses descriptive methods, the method used to describe a phenomenon clearly and in detail, where the researcher is only as a reporter (giver of information) in accordance with the results of the study. ${ }^{3}$

\section{Result and Discussion}

\section{A. Sentencing}

The term of sentencing (mordeling) is a synonymous to the word punishment. Sentencing is setting a sentence or deciding a sentence. Setting a sentence for an event does not only involve for criminal law but also applies to civil law. According to Barda Nawawi Arief, the definition of sentencing is broadly interpreted as a process of giving or imposing a crime by a judge, then it can be said that the criminal system includes the entire statutory provisions governing how the criminal law is enforced or operationally concretely so that a person is sanctioned. ${ }^{4}$

Sentencing is the stage of giving and setting sanctions/penalties in criminal law. The word "criminal" is generally interpreted as law, while "sentencing" is interpreted as punishment. The purpose of the sentencing is intended as an effort to foster perpetrators of crimes as well as preventive efforts to avoid similar crimes.

According to Andi Hamzah, the meaning of sentencing is an arrangement and method in sentencing. ${ }^{5}$ The system is a combination of several elements into one function. The Criminal system is a statutory regulation relating to criminal sanctions. The broad understanding of the criminal system can be interpreted as a process of giving or imposing a criminal sentence by a judge, so it can be said that the criminal system includes the entire statutory provisions governing how the criminal law is enforced or operationally concretely so that a person is sanctioned. ${ }^{6}$ The penal system in modern criminal law is oriented towards perpetrators and deeds (daad-dader straafrecht) so that the type of sanctions stipulated not only includes criminal sanctions, but also sanctions that are relatively educational in nature rather than suffering. ${ }^{7}$

The purpose of sentencing is to promote the welfare, balance, and harmony in social life by paying attention to the interests of the community/state, victims, and perpetrators. ${ }^{8}$ Based on this purpose, the sentencing must contain the element is

a. Humanity, in the sense that the conviction upholds the dignity of a person.

b. Educative, in the sense that punishment can make people aware of their actions and cause it to have a positive and constructive mental attitude for crime prevention efforts.

\footnotetext{
${ }^{2}$ Leli Joko Suryono, (2018). Buku Pedoman Penulisan Hukum. Yogyakarta: Universitas Muhammdiyah Yogyakarta. p. 26.

3 Ibid.

${ }^{4}$ Barda Nawawi Arief. (2003). Kapita selekta hukum pidana. Bandung: Citra Aditya Bakti. p.136.

${ }^{5}$ Andi Hamzah. (1986). Sistem Pidana dan Pemidanaan Indonesia. Jakarta: Pradnya Paramita. p. 1.

${ }^{6}$ Failin. (2019). Sistem Pidana dan Pemidanaan di dalam Pembaharuan Hukum Pidana Indonesia. Jurnal Cendekia Hukuma, 3(1). p. 19.

${ }^{7}$ M. Sholehuddin. (2003). Sistem Sanksi Dalam Hukum Pidana. Jakarta: Raja Grafindo Persada. p. 58.

${ }^{8}$ Ibid. p. 59.
} 
c. Fairness, in the sense that the punishment is felt to be fair both by the convicted and by the victim or by the community. ${ }^{9}$

\section{B. Minors}

Children are a generation figure of the nation as potential human resources to continue the ideals of the nation's struggle. Understanding children has a broad meaning so that children can be categorized into several age groups, namely childhood (aged 0-12 years), adolescents (aged 13-20 years), and adulthood (aged 21-25 years). Children tend to have traits that like to imitate and follow what they see. Children need protection to ensure their growth and development both physically and mentally. As a legal subject, children are still considered incapable because they are still under the age where their mental and physical conditions are still developing.

Laws and regulations in Indonesia in providing definitions of children there are some differences or, but in each of these differences understanding has been adjusted based on the situation and conditions. The definition of a child is also contained in Law Number 4 Year 1979 concerning Child Welfare in Article 1 paragraph (2) which stated "A child is someone who has not reached the age of 21 (twenty-one) years old and has never been married".

Children's rights are protected in Law Number 17 of 2016 concerning Determination of Government Regulation on Replacement of Law Number 1 of 2016 concerning the second amendment of Law Number 23 of 2002 on Child Protection. Article 1 paragraph 1 explains that the category of underage children is a child under 18 (eighteen) years including children who are still in the womb. The legal protection given to children aims to guarantee and protect children from their rights such as the right to live, grow, develop, participate optimally in accordance with dignity, and get protection from violence and discrimination. This child protection is explained in article 1 paragraph 2 Law Number 17 of 2016 concerning Determination of Government Regulation on Replacement of Law Number 1 of 2016 concerning the second amendment of Law Number 23 of 2002 on Child Protection. Child protection is an effort to protect children to carry out their rights and obligations. These efforts are aimed at preventing, rehabilitating, and empowering children from mistreatment, exploitation, neglect to live a good life physically, mentally, and socially.

\section{Children Confronted to the Law}

The definition of minor in Penal Code (KUHP) Article 45 stated that "minor is not yet mature if they are not yet 16 (sixteen) years old. If a minor is caught in a criminal case, the judge can order that the child who is caught in a criminal case be returned to his parents, guardians, or foster parents, without a criminal or order to be handed over to the government without a criminal or convicted by a reduction of $1 / 3$ (one-third) from the maximum threat of 15 years."

Juvenile delinquency in a broad sense is the actions of adolescents who violate the written law contained in legislation inside and outside the Penal Code. Juvenile delinquency can also be in the form of acts that are anti-social, disturbing the public even though it is not classified as a general criminal offense or special criminal offense. The actions of adolescents who are classified as anti-moral are also included as juvenile delinquency for example, are acts that violate religious norms such as do not practice worship.

According to Bimo Walgito, Juvenile Delinquency is an act against the law committed by adolescents, if the act is committed by an adult then the act is a crime. ${ }^{10}$ In the book Inleiding tot de Criminologie by W.A. Bonger argues that the crime of children and adolescents is a big part of the crime, adult offenders generally have committed crimes since childhood so prevention of committing crimes since children will have a good effect on prevention of committing crimes by adults. ${ }^{11}$

In article 1 paragraph 2 Law number 3 Year 1997 mentions the definition of naughty child namely:

1. Children who commit crimes.

\footnotetext{
${ }^{9}$ Ibid.

${ }^{10}$ Bimo Walgito. (1991). Psikologi Sosial. Yogyakarta: Andi offset. p. 10.

${ }^{11}$ Ninik Widiyanti\&Yulius Waskita. Kejahatan dalam Masyarakat dan Pencegahannya. Jakarta: Bima Aksara. p. 115.
} 
2. Children who commit acts that are prohibited for children, both according to the laws and regulations according to other legal regulations that live and apply in the community concerned.

According to Law number 11 Year 2012 concerning the Juvenile Court System (Sistem Peradilan Pidana Anak) it is explained that the definition of a children confronted to the law is someone who is 12 (twelve) years old, but not yet 18 (eighteen) years old who is suspected of committing a crime. Based on Law No. 11 of 2012 concerning the Juvenile Court System (SPPA), there are 3 (three) groups regarding children who are confronted with the law, namely:

1. A child suspected of having committed a crime in which the child is 12 years old but has not reached 18 years can be said to be a child in conflict with the law.

2. A child who is not yet 18 years old who have suffered suffering and caused physical and mental harm to the child, which is also referred to as children who are victims of criminal acts.

3. A child who is not yet 18 years old in which the child can provide information to apply justice in a criminal case that is heard, seen, and experienced. Therefore the child is categorized as a child who is a witness of a crime. ${ }^{12}$

\section{Sexual Abuse}

Violence is not only interpreted physically but also mentally and even passively. ${ }^{13}$ Sexual abuse is an act in the form of coercion of sexual relations in an unnatural and unwelcome manner, coercion of sexual relations for commercial purposes, or specific purposes. ${ }^{14}$ Forms of sexual violence can take the form of oral-genital, genital-genital, genital-rectal, genital-hand, rectal-hand, breast-hand, sexual anatomy, forced viewing, and showing pornography. ${ }^{15}$

Sexual abuse is sexual activity that is accompanied by an element of violence. The element of violence can be in the form of assault and without assault. Sexual violence with a category of assault that is causing suffering in the form of physical injury, while the category of sexual violence without attack that is causing emotional trauma. ${ }^{16}$ Forms of sexual violence can include seduction, being poked, being hugged forcefully, squeezing, forced masturbation, oral sex, child sex, rape, etc. Sexual relations between adults and children under the age of 14 (fourteen) years can be referred to as "statutory rape" whereas if done with children under 16 (sixteen) years old is referred to as "carnal connection".

There are two types of sexual abuse based on the identity category of the perpetrators, namely:

\section{a. Familial Abuse}

Familial abuse is incest, which is sexual violence where there is a blood relationship between the victim and the perpetrator or becomes a part of the family. This blood relation also includes someone who is a surrogate parent, for example, a stepfather/mother, caregiver, or someone who is trusted to take care of children. According to Mayer, the category of incest in families in child abuse, namely the first category is sexual molestation, this includes non-coitus interactions, petting, fondling, exhibitionism, and voyeurism, all matters relating to sexually stimulating perpetrators. ${ }^{17}$ The second category is rape (sexual assault), in the form of oral or genital relations, masturbation, oral stimulation of the penis (fellatio), and oral stimulation of the clitoris (cunnilingus). The most fatal last category is called forcible rape, which includes sexual contact. Fear, violence, coercion, and threats become difficult for victims to resist the perpetrators.

\footnotetext{
${ }^{12}$ R. Wiyono. (2016). Sistem Peradilan Pidana Anak di Indonesia. Jakarta: Sinar Grafika. p. 14-15.

${ }^{13}$ Gultom Maidin. (2012). Perlindungan Hukum terhadap Anak dan Perempuan. Bandung: PT Refika Aditama. p. 83.

14 Jalaluddin Rakhmat. (2007). SQ FOR KIDS: Mengembangkan Kecerdasan Spiritual Anak Sejak Dini. Bandung: Mizan. p. 112.

${ }^{15}$ Ratih Probosiwi\&Daud Bahransyaf. (2013). Pedophilia and Sexual Violence: Problem and Child Protection. Sosio Informa. 1( 1). p. 32.

${ }^{16}$ Gultom Maidin, Op. Cit., p. 3.

${ }^{17}$ Ivo Noviana. (2015). Child Sexual Abuse: Impact and Handling. Sosio Informa. Vol. 01, No. 1. p. 15.
} 


\section{b. Extra Familial Abuse}

Extra familial abuse is violence perpetrated by other people outside the victim's family. The perpetrator is usually an adult known by the child, then entices the child into the situation where sexual abuse occurs. The perpetrator gives certain rewards for persuading the child to obey his wishes. Some parents are sometimes less concerned about the existence of their child and with whom they spend time, so children are more vulnerable to incidents of sexual harassment and must be watched out for.

\section{E. Factors that Stimulate Minors to Do Sexual Abuse}

The impact of the development in the digital era, children begin to affected by negative things that causing many cases of children who commits a crime or deviations and it's called juvenile delinquency. The lack of education and supervision of children in the use of social media makes it easy for children to access issues for example sites that contain pornography. That is the reason why children who commit sexual abuse crimes in the form of obscene action and sexual intercourse.

According to the interviewees from Aiptu Nikmatun Nurjanah, Head of the Women and Children Services Unit (Pelayanan Perempuan dan Anak/PPA) at Sub Regional Police Kebumen (Polres Kebumen) and Dra Sri Wahyuningsih Head of the Division Protection the Rights of Women and Children (Perlindungan Hak Perempuan dan Anak), Community and Village Empowerment Agency and Women's Empowerment and Child Protection Services (Dinas Pemberdayaan Masyarakat dan Desa dan Pemberdayaan Perempuan dan Perlindungan Anak/ Dispermades P3A) Kebumen Regency it can be concluded that the factors that influence children to become a perpetrator of sexual abuse are an internal factor and external factor.

\section{Internal Factor}

Internal factors are factors that come from within yourself such as feelings that arise in the heart or soul. Factors in the self include insecurity, poor concentration, anxiety, and impulsive. ${ }^{18}$ In the case of children becoming a perpetrator of sexual abuse, usually come from the internal factors in the form the sexual desires of the perpetrators. Internal factors that influence sexual behavior are usually more common in men. Children under 18 years are new to puberty where they will be very curious about sexual activity. Because of these sexual desires, children will look for and try a new things related to sex without knowing the effect. To fulfill their sexual desires, children usually take it out by looking at pornographic photos and videos. From the pornography photos and videos, comes the motivation to be supported by other external factors.

\section{External Factor}

a. Lack of Parental Supervision

Parents are responsible for the lives of their children, especially when their children are still underage. In educating children, parents will provide supervision and attention to support the physical and psychological health of the child. As a good parent must be able to guarantee the implementation of family functions. The parental behavior can also affect children such as parents who use abuse in their actions, the criminality of the parents, mothers who are still teenagers or young, marriage disputes, domestic violence, child neglect, and lack of parental supervision. Among the family functions, the protective functions of the family are needed to be optimized to face the negative dangers of the digital era so that children are not victimized by irresponsible communication media users. Most of the children who become victims and even criminals, are caused by the lack of parental supervision. Parents who are too busy with their activities such as work are considered not paying attention to the child's daily activities. Most parents think that education at school is enough for children, even though the most important education is education at home by both parents. This is a gap where children can carry out activities without the supervision of the parents, so it is easy for the children to fall into negative things. ${ }^{19}$

${ }^{18}$ Khoirunita Ulfiyatun Rochmah. (2015). Dinamika Psikologi Anak Pelaku Kejahatan Seksual. Jurnal Psikologi Tabularasa. 1( 1). p. 91.

${ }^{19}$ Sri Murni. (2015). Optimalisasi Pengawasan Orang Tua terhadap Bahaya Pelecehan Seksual pada Anak di Era Digital. KOLOKIUM Jurnal Pendidikan Luar Sekolah. 5( 2). p. 155. 


\section{b. Environmental Influence}

A child does not always interact with their family. A child will get another group to interact with either relatives, neighbors, or school friends. Children will form bonds with playmates and will slowly influence their patterns and behavior. ${ }^{20}$ Relationships with parents can be realized in a different form than before while interactions with friends will become more intimate so that at this time, they will experience dating and sexual exploration and the possibility of having sexual relations. Sexual exposure obtained by children is usually obtained from listening to or seeing people who are kissing, embracing, seducing, and having sex to encourage children to have sex. ${ }^{21}$ All of this means that the sexual behavior exhibited by adolescents is caused by many environmental factors that can bring children to carry out risky sexual activities. This is because of the time spent by children playing with their peers sometimes more than other activities so that children are very easily influenced.

\section{c. Lack of Education}

The importance of education for children will greatly influence their lives in the future. Errors in providing education can affect children's behavior where there will be juvenile delinquency. Factors of lack of education such as academic failure, dropping out of school, ditching are the causes of juvenile delinquency, especially sexual abuse.

In cases of sexual abuse with child offenders, it is most likely a factor in the educational side due to a lack of understanding of sex or lack of sex education. Sex education is learning about the cognitive, emotional, social, interactive, and physical aspects of sexuality. ${ }^{22}$ It aims at supporting and protecting sexual development. It gradually equips and empowers children and young people with information, skills, and positive values to understand and enjoy their sexuality, have safe and fulfilling relationships, and take responsibility for their own and other people's sexual health and well-being. ${ }^{23}$ Sexuality education delivered within a safe and enabling learning environment and access to health services have a positive and effect on the health of children. Good quality of sex education has an impact on positive attitudes and values for children in contributing to the prevention of abuse and fostering mutually respectful and consensual partnerships.

\section{d. Mass Media}

Mass Communication Media is communication tools to spread news or message to the public. The mass media consists of print media and electronic media. The impact of technological developments, it is increasingly for people to access the internet and social media both by adults and children. The influence of social media has advantages and disadvantages, especially for children. The use of social media by children which is done well with parental supervision will have a good effect on their future, but if there is a misuse of social media by children to access inappropriate things, it will adversely affect their growth and development. The risk of using social media can cause cyberbullying and online harassment. The other risk of using social media is sexting (sex texting) or pornography. Sexting can be defined as sending, receiving, or forwarding sexually explicit messages, photographs, or images via cell phone, computer, or other digital devices. ${ }^{24}$

Online pornography content is always "on" and is portable, allowing access at any time and in any place. The negative effect of accessing pornography such as children or adolescents may experience autonomic sexual arousal at the sight of pornography, which can confuse them into thinking they "like" what they see, when in fact their bodies are reacting instinctively without the "approval" of their brain. ${ }^{25}$ Because of these impacts, it can be a motivation of children to do sexual crime especially sexual abuse where children will force other children to do the sexual things.

\footnotetext{
${ }^{20}$ Rahman Taufiqrianto Dako. (2012). Kenakalan Remaja. Jurnal Inovasi, 9(2). p. 4.

${ }^{21}$ Khoirunita Ulfiyatun Rochmah, Op.Cit., p. 94.

${ }^{22}$ Taylor \& Francis. (2015). Sex Education. European Expert Group on Sexuality Education, 16(4). p. 428.

23 Ibid.

${ }^{24}$ Gwenn Schurgin et all. (2011). The Impact of Social Media on Children, Adolescent, and Families. Pediatrics, 127(4). p. 802.

25 Cordelia Anderson, "Promoting Health Sexuality: Understanding The Effect of Pornography on Your Children", www.preventchildabuse.org/ accessed on $7^{\text {th }}$ May 202023.54 .
} 


\section{F. Consideration of the Judges in Sentencing Minors as Perpetrators of Sexual Abuse}

Sentencing for children is regulated in Law No. 11 of 2012 on Juvenile Court System. This law becomes the basis by the judge in giving sentence on children as perpetrators of criminal acts. There are two forms of penalties for children, namely the criminal penalties and the action penalties. The sentencing is intended to give a deterrent effect on child offenders so that there are no repeated criminal acts. Also besides, children are also given criminal penalties instead of fines in the form of work training intended to provide knowledge for children after finishing the sentence. Children are also attempted to be diversified as a form of criminal relief while being able to settle a child's case outside the court and be kept away from prison. This is intended to minimize negative stigma from the community such as being ostracized and labeled as naughty children or criminal children because such actions can affect the child's psychic.

The system of sentencing for minors is regulated in Law No. 11 Year 2012 concerning Juvenile Court System (Sistem Peradilan Pidana Anak/ SPPA) which regulates about children confronted to law, namely child perpetrators, child victim, and child witness. The Law on Juvenile Court System uses the restorative justice and diversion approaches in resolving criminal cases committed by children. Definition of Restorative Justice in article 1 paragraph (6) Law No. 11 Year 2012 concerning the Juvenile Court System (Sistem Peradilan Pidana Anak/ SPPA) is the settlement of criminal cases involving the perpetrators, victims, families of the perpetrators/ victims, and other related parties to jointly seek a fair solution by emphasizing recovery in its original state, and not retaliation.

Child cases can be resolved through non-formal mechanisms based on standardized guidelines. Forms of non-formal handling can be done with diversion as a mediation process facilitated by law enforcement at every level to achieve restorative justice that can be resolved by requiring children who conflict with the law to attend education or training at good and professional LPKS and LPKA institutions as is done with restoration for children and victims, or if forced to do punishments of children's rights should not be ignored. ${ }^{26}$ Diversion is the transfer of the settlement of children from the criminal justice process to outside the criminal justice process trough by deliberation and resolved by deliberation so the children are not stigmatized negatively due to the judicial process. Under Law No. 11 Year 2012 concerning Juvenile Court System (Sistem Peradilan Pidana Anak/ SPPA), the diversion is done through deliberations involving the child and the parent/guardian, the victim and/or parent/guardian, the civic, and the supervising social worker professionals.

The implementation of diversion on the Juvenile Court System will avoid the stigmatization from society to children as being bad child because of their criminal acts. Diversion is granted because it fits with the philosophy of the Juvenile Court System to protect and rehabilitate child criminals. ${ }^{27}$ Also besides, diversion is also performed as prevention of children become criminals in adults. ${ }^{28}$

Diversion has purposes as explained in article 6 Law No. 11 Year 2012 concerning the Juvenile Court System (Sistem Peradilan Pidana Anak/ SPPA):

a. Achieving peace between victims and children;

b. Settle the Children case outside the judicial process;

c. Prevent children from deprivation of independence;

d. Encourage the community to participate;

e. Instill a sense of responsibility to the children.

The diversion is granted with the following conditions in accordance with Article 7 Paragraph (2) Law No. 11 Year 2012 concerning the Juvenile Court System (Sistem Peradilan Pidana Anak/SPPA):

a. Threatened with imprisonment of under 7 (seven) years;

b. Not a repeat of criminal offense

\footnotetext{
${ }^{26}$ Nevey Varida Ariani. (2014). Implementasi Undang-Undang Nomor 11 Tahun 2012 tentang Sistem Peradilan Pidana Anak dalam Upaya Melindungi Kepentingan Anak . Jurnal Media Hukum. 21(1). p. 116-117. 
In Law on Juvenile Court System (Sistem Peradilan Pidana Anak/SPPA), the provisions regarding special minimum criminal threats for children that proven to committed a criminal offense is no longer applied. According to the Law on Juvenile Court System (Sistem Peradilan Pidana Anak/ SPPA), a child perpetrator is charged with two kinds of sanctions, action, for perpetrators under 14 years old, and penal, for 15 years old or above perpetrators. ${ }^{29}$ Action Sanction based on Article 82, paragraph (1) Law No. 11 of 2012, the sanctions are:

1. Return to parents/guardian;

2. Surrender to someone;

3. Treatment at a mental hospital;

4. Social Welfare Management Institutions (Lembaga Penyelenggaraan Kesejahteraan Sosial/ LPKS);

5. Obligation to pursue formal education and/or training provided by the government or private institutions;

6. Driver's license revocation; and/or

7. Criminal damage repair.

Penal Sanction According to Article 71 Law No. 11 of 2012, the criminal sanctions which are subjected to child perpetrators are divided into Principal Penal and Additional Penal:

1. Principal Penal:

a. Warning Penalty;

b. Conditional Penalty:

c. Work Training;

d. Fostering inside the Institution;

e. Imprisonment.

2. Additional Penal:

a. Deprivation of profits derived from criminal acts;

b. Fulfillment of customary obligations.

3. If in the material law there is a cumulative penalty in the form of prison and fines, the criminal fines are replaced by job training.

4. Penalties handed down to children are prohibited from violating the dignity of the child.

5. Further provisions regarding the form and procedure of the criminal conduct as referred to in paragraph (1), paragraph (2), and paragraph (3) shall be regulated by Government Regulation.

In the material law, there is a cumulative criminal threat in the form of fines and imprisonment, then the fines are replaced by job training without any provision that the fines are not paid as in the provisions of the Juvenile Court Law so that work training is automatically imposed if cumulatively proven in material law is proven thus.

Diversion efforts for children must comply with the conditions that stated in Law No. 11 of 2012 on the Juvenile Court System if they do not qualify the requirements, the perpetrators of children will still be subjected to punish in accordance with the regulation for the punishment of children in Law No. 11 of 2012 on Juvenile Court System. In Article 79 paragraph (2) and Article 81 paragraph (2) Law No. 11 of 2012 on the Juvenile Court System explains that the criminal restriction of freedom imposed on children is a maximum of $1 / 2$ (half) of the maximum imprisonment sentenced to adults, and in article 81 paragraph (2) Law No. 11 of 2012 on the Juvenile Court System explains that imprisonment that can be imposed on children no later than $1 / 2$ (one-half) of the maximum threat of imprisonment for adults. Based on this article, it can be concluded that in cases of sexual violence that is sexual abuse and promiscuity where the 
perpetrators are children can be sentenced to a maximum prison sentence of $1 / 2$ (half) of the maximum threat of imprisonment against adults, namely imprisonment for 7.5 (seven commas five) years from the maximum sentence of imprisonment for adults which is 15 (fifteen) years in prison. The judge will not decide on a sentence of imprisonment for a child of more than 7.5 (seven point five) years because the term of imprisonment for a child offender of sexual violence is a maximum of 7.5 (seven point five) years.

Judge's considerations can be juridical and non-juridical. Juridical considerations are judge's considerations based on the factors revealed in the trial and by law have been determined as matters that must be included in the decision. Juridical considerations include:

a. Public prosecutor's indictment.

b. Witness Statement.

c. Defendant Statement.

d. Evidence Tools.

e. Articles in the Criminal Act Law

Non-juridical considerations are also called sociological. Judicial considerations are sociologically regulated in Article 5 paragraph (1) of Law No. 48 of 2009 concerning Judicial Power which states that judges are required to explore, follow and understand the legal values and a sense of justice that lives in society. Factors that must be considered sociologically by the judge to decide a decision on a case include:

a. Paying attention to unwritten legal sources and values living in society.

b. Look into the good and bad habit of the defendant as well as the values that lighten up and the things that burden the defendant.

c. Look into the peace, error, the role of the victim.

d. Community factors, the environment in which the law applied.

\section{Judges Consideration Court Decision Number 2/Pid.Sus-Anak/2018/PN Kbm}

The judge considered the single indictment as regulated in Article 82 paragraph (1) of Law Number 23 of 2002 as amended and added by Law Number 35 of 2014 concerning Amendment to Law Number 23 of 2002 concerning Child Protection the elements are as follows:

\section{Every person ;}

2. Violating the provisions of Article $76 \mathrm{E}$, it is prohibited to commit violence or threat of violence, force, commit deception, commit a series of lies, or persuade children to commit or allow obscene acts to be carried out;

Considering, that because all the elements in the Single Indictment of the Public Prosecutor have been fulfilled for themselves and the actions of the child, the indictment has been proven legally and convincingly that the child is guilty of committing a criminal offense which qualifications are: "Intentionally Persuading Children To Conduct Or Allow Obscene Acts";

Considering, that during the hearing in the trial, the Judge did not find things that could eliminate criminal liability either as an excuse or justification for reasoning then the child must be responsible for his actions;

Considering, that based on the conclusions from the Community Research Results (Litmas), the Community Guidance advises in the best for the interest of the child Romadhona (name obscured) was decided by the Criminal Penalty with requirements of supervision, according to article 71 paragraph 1 letter (b) 3rd of RI Law number 11 years 2012 concerning the Juvenile Criminal System;

Considering, that before imposing a crime against a child it is necessary to consider first the incriminating and mitigating circumstances: 
Incriminating Circumstances :

a. The actions of child Romadhona (name obscured) have made the victim's witness experience a psychological disorder;

b. The act of child Romadhona (name obscured) is despicable and violates the values of decency;

c. The act of child Romadhona (name obscured) can ruin the future of the witness;

a. Mitigating Circumstances :

d. Child Romadhona (name obscured) realizing his actions ;

e. Child Romadhona (name obscured) feel regret for his action;

f. Child Romadhona (name obscured) has never been convicted ;

In considering appropriate sentences for defendants, judges use judicial and non-juridical considerations. Juridical considerations are judge's considerations that are based on juridical facts that are revealed in a trial and determined by law to be contained in a decision. Juridical considerations in this case include that the defendant has fulfilled the elements of the article charged by the Public Prosecutor, the defendant has admitted his actions and based on evidence and witnesses statements it can be concluded that the defendant was proven guilty of obscene action against a minor. According to Article on criminal law, the defendant has violated Article 82 paragraph (1) of Law Number 23 of 2002 as amended and added by Law Number 35 of 2014 concerning Amendment to Law Number 23 of 2002 concerning Child Protection.

Non-juridical/ sociological considerations are judge's considerations that pay attention to nonjuridical factors, such as moral values living in the community and judges decisions based on faith, good moral integrity, and taking into justice for people. Non-juridical considerations in this case, include the background of the perpetrator who committed obscene action where he was influenced by the persuasion of his friends, the actions of the perpetrators have caused physical injuries and psychological disorder, but the perpetrators cooperate in the trial process by acknowledging their actions and feeling guilty.

Based on the judge's consideration and based on Article 82 paragraph (1) of Law No.35 of 2014 concerning Amendments to Law No.23 of 2002 concerning Child Protection, Article 69 paragraph (2) and Article 82 of Law of the Republic of Indonesia Number 11 of 2012 concerning Criminal Justice System for Children, Law No. 8 of 1981 concerning Criminal Procedure Law, as well as other relevant laws and regulations, the child Romadhona (name obscured) is sentenced to a prison sentence of 1 (one) year and 8 (eight) months in LPKA Kutoarjo and sentenced to work training for 3 (three) months based on Decision Number 2/Pid.Sus-Anak/2018/PN Kbm.

\section{Judges Consideration Court Decision Number 2/Pid.Sus-Anak/2018/PN Kbm}

Based on the analysis results and conclusions in the Community Research above and strengthen by the recommendation of the Correctional Observer Team Session and the approval of the Head of BAPAS Purwokerto on September 25, 2019, the Social Supervisor give opinions that the actions of the Client Ferry (name obscured), 15 years old complete the elements of Article 81 Paragraph (1) of Law Number 17 of 2016 concerning Determination of Government Regulation on Replacement of Law Number 1 of 2016 concerning the second amendment of Law Number 23 of 2002 on Child Protection, then the Community Supervisor recommends that the Client be given a decision in the form of Criminal In Institution in accordance with Article 71 paragraph (1) letter d of Article 80 concerning the Juvenile Criminal System in Pondok Pesantren Tarbiyatul Athfal School, Jl Wadaslintang Km 17 Prembun Village/ Padureso District, Kebumen Regency.

Considering, that in the hearing process, the Panel of Judges did not find things that could eliminate criminal liability, both as justification and/ or reasons for forgiveness, then the offender must be responsible for his actions;

Considering, that due to the indictment of the article on the child Feri (name obscured) is the cumulative criminal threat, namely imprisonment and fines, then the fines penalties are replaced in accordance with Article 71 paragraph (3) of Law No.11 of 2012 concerning Criminal Justice System for Children;

Considering, that before imposing a crime against a child it is necessary to consider first the incriminating and mitigating circumstances: 
Incriminating Circumstances:

a. The act of the child Feri (name obscured) has made the victim's experience a psychological disorder;

b. The actions of child Feri (name obscured) are disgraceful and violate moral values;

c. The act of the child Feri (name obscured) can damage the future of the victim;

1) Mitigating Circumstances:

d. The child admits his action;

e. The child feels guilty and regrets his actions;

f. The child is ready to marry the victim;

g. The child has never been punished.

In considering appropriate sentences for defendants, judges use judicial and non-juridical considerations. Juridical considerations are judge's considerations that are based on juridical facts that are revealed in a trial and also determined by law to be contained in a decision. Juridical considerations in this case, include that the defendant has fulfilled the elements of the article charged by the Public Prosecutor, the defendant has acknowledged his actions, and based on the evidence and witness's testimony it can be concluded that the defendant was proven guilty of having sexual intercourse with a minor. According to Article on criminal law, the defendant has violated Article 81 paragraph (2) of the Law of the Republic of Indonesia Number 17 Year 2016 concerning the Establishment of Government Regulation in Lieu of Law No. 1 of 2016 concerning the Second Amendment to Law R.I. No. 23 of 2002 concerning Child Protection becomes a law.

Non-juridical/ sociological considerations are judge's considerations that pay attention to nonjuridical factors, such as moral valuesliving in the community and judges decisions based on faith, good moral integrity, and taking into justice of the people. Non-juridical considerations in this case, include the perpetrator's actions causing physical injuries and psychological disorder for the victim and impact to the victim's future, but the perpetrators tried to cooperate in the trial process by acknowledging their actions, feeling guilty, and will be responsible for marrying the victim.

Based on the judge's consideration and look into the Article 81 paragraph (2) of the Law of the Republic of Indonesia Number 17 Year 2016 concerning Establishment of Government Regulation in Lieu of Law Number 1 of 2016 concerning the Second Amendment to Law Number 23 of 2002 concerning Child Protection, Law Number 11 of 2012 concerning the Criminal Justice System for Children, Law Number 8 of 1981 concerning Criminal Procedure Law, and other relevant laws and regulations, then the child Feri (name obscured) is sentenced to imprisonment for 2 (one) year and 6 (eight) months in LPKA Kutoarjo and a substitute criminal for conducting social services in the form of preparing all necessities before the Maghrib Prayer and Isya Prayer in the congregation at the Pondok Pesantren Tarbiyatul Athfal Mosque Jl. Wadaslintang KM 17 Prembun Padureso District, Kebumen Regency for 2 (two) months based on decision ruling Number 2/Pid.Sus-Anak/2018/PN Kbm.

\section{Conclusion}

Based on the research result and discussions that have been conducted regarding sentencing for minors who committed sexual abuse in Kebumen Regency, the authors concluded as follow:

1. Based on the analysis conducted by the author for the factors that stimulate minors to do sexual abuse, there are 2 kinds of factors namely internal factors and external factors. Internal factors are factors that come from within yourself. In the case of children becoming perpetrators of sexual abuse usually, internal factors come from the sexual desires of the perpetrators. External factors are factors that come from outside the self such as the environment, the influence of social media even due to lack of parental supervision and education.

2. Based on the analysis conducted by the author regarding sentencing for minors who committed sexual abuse based on Court Decision Number 2/Pid.Sus-Anak/2018/PN Kbm and Court Decision Number 14/Pid.Sus-Anak/2019/PN Kbm that in cases of sexual abuse those are obscene action and sexual intercourse can not diversion because it does not meet the requirements of diversion where the 
threat of criminal punishment is more than 7 years, so the case is continued in the juvenile justice process. In considering appropriate sentences for defendants, judges use judicial and non-juridical considerations. Juridical considerations are judge's considerations that are based on juridical facts that are revealed in a trial and are determined by law to be contained in a decision. Non-juridical/ sociological considerations are judge's considerations that pay attention to non-juridical factors, such moral values living in the community and judges decisions based on faith, good moral integrity, and taking into the sense of justice. This non-juridical consideration makes the situation even more burdensome and even alleviates the punishment of the perpetrators.

\section{References}

\section{Books}

Andi Hamzah. (1986). Sistem Pidana dan Pemidanaan Indonesia. Jakarta: Pradnya Paramita.

Barda Nawawi Arief. (2003). Kapita selekta hukum pidana. Bandung: Citra Aditya Bakti.

Bimo Walgito. (1991). Psikologi Sosial. Yogyakarta: Andi offset.

Gultom Maidin. (2012). Perlindungan Hukum terhadap Anak dan Perempuan. Bandung: Refika Aditama.

Jalaluddin Rakhmat. (2007). SQ FOR KIDS: Mengembangkan Kecerdasan Spiritual Anak Sejak Dini. Bandung: Mizan.

Leli Joko Suryono. (2018). Buku Pedoman Penulisan Hukum. Yogyakarta: Universitas Muhammdiyah Yogyakarta.

M. Sholehuddin. (2003). Sistem Sanksi Dalam Hukum Pidana. Jakarta: Raja Grafindo Persada.

Ninik Widiyanti\&Yulius Waskita. Kejahatan dalam Masyarakat dan Pencegahannya. Jakarta: Bima Aksara.

R. Wiyono. (2016). Sistem Peradilan Pidana Anak di Indonesia. Jakarta: Sinar Grafika.

\section{Journals}

Claudia Carolina Indra Putri. (2019). Juridical Review of Restorative Justice in the Juvenile Justice System through Diversion. Indonesian Journal of Criminal Law Studies 4(1).

Failin. (2019). Sistem Pidana dan Pemidanaan di dalam Pembaharuan Hukum Pidana Indonesia. Jurnal Cendekia Hukuma, 3(1).

Gwenn Schurgin O'Keeffe et all. (2011). The Impact of Social Media on Children, Adolescent, and Families. Pediatrics. 127(4).

Ivo Noviana. (2015). Child Sexual Abuse: Impact and Handling. Sosio Informa. 1(1).

Khoirunita Ulfiyatun Rochmah. (2015). Dinamika Psikologi Anak Pelaku Kejahatan Seksual. Jurnal Psikologi Tabularasa. 1(1).

Nevey Varida Ariani. (2014). Implementasi Undang-Undang Nomor 11 Tahun 2012 tentang Sistem Peradilan Pidana Anak dalam Upaya Melindungi Kepentingan Anak. Jurnal Media Hukum. 21(1).

Rahman Taufiqrianto Dako. (2012). Kenakalan Remaja. Jurnal Inovasi. 9(2).

Ratih Probosiwi\&Daud Bahransyaf. (2015). Pedhopilia and Sexual Violance: Problem and Child Protection. Sosio Informa. 1(1).

Sri Murni (2015). Optimalisasi Pengawasan Orang Tua terhadap Bahaya Pelecehan Seksual pada Anak di Era Digital. KOLOKIUM Jurnal Pendidikan Luar Sekolah. 5(2).

Taylor\&Francis. (2015). Sex Education. European Expert Group on Sexuality Education. 16(4).

\section{Legislation}


The Penal Code (Kitab Undang-undang Hukum Pidana/KUHP).

Law No.11 of 2012 concerning the Juvenile Court System.

Law Number 17 of 2016 concerning Determination of Government Regulation on Replacement of Law Number 1 of 2016 concerning the second amendment of Law Number 23 of 2002 on Child Protection.

\section{Internet}

Cordelia Anderson, "Promoting Health Sexuality: Understanding The Effect of Pornography on Your Children", www.preventchildabuse.org/ accessed on 7th May 202023.54. 